\title{
Günümüz Ana Akım Gazetelerinde Gazetecilik ve Edebiyat İlişkisi Üzerine Bir İnceleme
}

\author{
Erkan Turana, Hakan Alp ${ }^{b^{*}}$ \\ a,b Fenerbahçe Üniversitesi, İletişim Fakültesi, İstanbul.
}

\begin{abstract}
$\ddot{O} z$
Temeli insan öykülerine, yaşanmışlıklara dayanan edebiyat, sözün her türlü zenginliklerini kullanma sanatı olarak tanımlanabilir. Elde edilen bilgi ve verileri gerçeğin aktarılması ve resmedilmesi için kullanan gazetecilikte ise aktarımı sözün ve dilin zenginlikleriyle anlatma isteği, gazetecinin edebiyata yaklaşımı açısından çeşitli dönemlerde denenmiştir. Tarihsel süreç içinde edebiyat ve gazetecilik kavramları yalnızca edebiyat ürünlerinin yazım tarzlarına yansıması olarak kalmamış aynı zamanda edebiyat ürünleri gazetecilik aracılı̆̆ılıla okurla buluşmuştur. Edebiyat ve gazetecilik kavramları geleneksel gazeteciliğin alışılmış formlarının ötesinde anlatısal yapısıyla içerik zenginleştirici bazen dolaylı bazen de doğrudan bir etkileşim içine girmiştir. Bir yandan edebiyat ürünlerinin gazetelerde yer alması diğer yandan ise edebiyata dair unsurlarm anlatıda kullamlması haber yazımında bir tarz olarak benimsenmesi edebiyat gazetecilik ilişkisi açısından iki ayrı özellik göstermektedir.
\end{abstract}

Anahtar Sözcükler: Gazetecilik, Edebiyat, Söylem, Metin, Dil

\section{An Investigation on the Relationship between Journalism and Literature on Contemporary Mainstream Journalism}

\begin{abstract}
Absract
Literature based on established human stories, experiences can be defined as the art of using all kinds of words. In journalism which uses the obtained information and data for transferring and portraying the truth, the desire to express the transfer with the richness of the word and language has been tried in various periods in terms of the journalist's approach to literature. In the historical process, the concepts of literature and journalism were not only reflected in the writing styles of literary products, but also literary products were introduced to readers through journalism. The concept of literature and journalism goes beyond the usual forms of traditional journalism into narrative structure, content enrichment, sometimes indirect and sometimes direct interaction. On the one hand, the use of literary products in newspapers, on the other hand, the use of narrative elements in narration, is a feature of news writing in terms of literature and journalism.
\end{abstract}

Keywords: Journalism, Literature, Discourse, Text, Language

\section{Gİiş}

Dil, söylem, kurmaca yapısına göre içerik ve şekil olarak farklı yapısal karakterde karşımıza çıkan ve günümüzde bir endüstriyel ürün olan gazetecilik, Manoff ve Schudson'un belirttiği gibi aslında diğer anlatı türlerine benzer şekilde mevcut bir sistem dizgesi bağlamında olup kendi formatik sınırlamaları içinde ilerlemektedir (Manoff ve Schudson, 1986). Gazeteciliğin haber üretim süreci bu alanda çalışma yapan çevreler kadar mesleki pratik içinde yer alanlarca da oluşturulan haber değeri ve içerik unsurları kavramlarıyla dolayımlanarak ortaya bir ürün sunmaktadır. Galtung; gazetecilik mesleğinin işleyişi için bir takım haber değerlendirme unsurları 
belirlemiş ve herhangi bir olayın muhabir tarafından haber olarak değerlendirilmesi için bu unsurlardan bir ya da birkaçını içermesi gerektiğini vurgulamıştır (Galtung ve Ruge, 1981). Bu değerler anlaşılırlık, uygunluk, zaman, kültürel önem, ciddiyet, uygunluk, devamlılık, birleştirme, sosyal-kültürel özellikler olarak belirlenmiştir. Geleneksel haber yazma yöntemlerinde bu içerik unsuru en yalın ve anlaşılır dilde formatlanarak okuyucuya ulaştırılmaktadır. Bu değerler gözetilerek oluşturulan haber dil ve formatı ise dönemsel özelliklere göre şekil değiştirmiştir. Özellikle Tanzimat dönemi gazeteciliği buna örnektir. O dönem eserlerini halka ulaştırmanın en önemli aracı olarak gazeteler geldiği için edebiyatçıların bile bizzat kendilerinin gazete çıkardıklarını görmekteyiz.

\section{LITTERATÜR}

Çı̆̆’a göre 19.Yüzyılın ortalarından itibaren, endüstriyel gazeteciliğin doğum yeri olan Amerika Birleşik Devletleri'nde ve İngiltere'de, gazetecilik partizan bir mücadele aracı olmaktan çıkıp bir iş kolu haline gelmiş, haber yazımı geleneksel ve edebi yazından kopmuştur (Çı̆̆, 2010).

Aslında tarihsel süreç içerisine bakıldığında edebiyatın gazetecilikle yakından ilişkili dönemler yaşadığını görebiliriz. Aktaş’a göre edebî metnin yapısını meydana getiren bütün öğeler somut olarak vardır. Gerçek ve gerçeklik, günlük hayatta çok farklı görünüş ve kılıklarda karşımıza çıkar. Edebî metin, okuyucuda bir izlenim bırakmak, bir anlayış, bir duyuş uyandırmak kısacası onda estetik yaşantı adı verilen bir hâlin ortaya çıkmasını sağlamak amacıyla düzenlenir (Aktaş, 2015).

Aktaş'a göre edebi metinde üç anlatma yöntemi vardır. Anlatma-nakletme, coşkuyla dile getirme ve gösterme yoluyla anlatma. Gazetecilik de bu tür anlatım yöntemlerinden yararlansa da yukarıda bahsettiğimiz gibi artık endüstriyel tekniklerin yansıması olarak somut verilerle kolay anlaşılabilen belki dünya yüzeyinde standartlaşma boyutunda olan bir tarzla oluşturulan haberlerle okuyucuya ulaşmaktadır. Bu anlamda "haber metninin standart biçimi, yazma edimini belirli bir teknik ve kalıp içine sokarak edebiyatçılar gibi "seçkinlerin" elinden almakta, belirli bir eğitimden geçmiş "sıradan" insanın da kamusal alanda üretim yapmasını sağlamaktadır. Ters piramit dışındaki diğer gazetecilik metinleri, şu veya bu şekilde sıkı kuralların dışına çıkabilirler (makale, araştırma inceleme, köşe yazısı, dizi yazısı, kronolojik ve biyografik metinler vb.).

Duran'a göre, gazetecilik/habercilik akıl, fikir, bilgi, deşme, tahlil yani analiz ve sentez yapma yeteneği isteyen bir meslek. Hatta artık salt bir meslek olarak da tanımlanması yetersiz kalıyor. Çünkü gazetecilik, tıpkı avukatlık ya da doktorluk gibi, icra mekânı ve zamanı ile koşulları sınırlandırılamayan bir uğraş, hatta bir yaşam tarzı haline geliyor/gelmeli. Gazetecilik artık görünen arkasında gizleneni göstermek, olguyu/ olayı tüm boyutlarıyla açığa çıkarmak, gelişmenin nedenlerini, diğer olgularla ilişkilerini faş etmek, yurttaşın düşünce ufkunu genişletmek, okuru aktif yurttaş haline getirmek için dürtmek gibi işlevlere de sahip (Duran, 2017). 


\section{YÖNTEM}

Makalemiz kapsamında, günümüzde Türk basınında edebi gazetecilik ve edebi içeriklerin kullanılıp kullanılmadığını ortaya koymak için tirajları en yüksek dört gazete seçilerek bir haftalık haberlerin analizi yapılmıştır. Berger'in Media Research Technıques (Berger, 1982) çalışmasında önerdiği içerik analizi yöntemiyle, Aktaş'ın edebi metinleri çözümleme yöntemi, araştırmamızın temelini oluşturacaktır.

Berger'e göre içerik analizi, bir araştırma tekniği olup bir şeyin miktarını ölçmeye yarar. İçerik analizi yöntemi; şiddet, kadın araştırmaları, aile vb. gibi konularda olabileceği gibi temsili bir örnekleme, bir kitle aracılı popüler sanat formunun, örneğin bir gazete çizgi romanının analizleri şeklinde de yapabilir. Bunun dışında olayların içerik analizi de yapabilir. İçerik analizi, mevcut bir şeyi öğrenmeye çalışmak için bir araçtır. Yazılanları, televizyon içeriklerini, filmleri davranış kalıplarını, değerleri, tutum ve davranışları yansıtır ve etkiler.

\subsection{Gazetecilik Ve Edebiyat İlişkisi}

Gazetecilikle edebiyat arasındaki ilişkiyi açıklayabilecek olan en önemli çalışmalardan biri Robinson Cruzo adlı eserdir. Yazarı Daniel Defoe gerçek doküman ve belgelere dayanarak veba azabını yaşamış olan insanların içinde bulundukları durumu korkularını, duygularını tarafsız anlattığı Veba Yılı adlı eseri edebi gazetecilik açısından ilk denemelerden biri olarak görülebilir. $\mathrm{O}$ dönem edebi gazetecilik adına önemli bir çalışma olan veba yılıyla ilgili geçtiğimiz günlerde yapılan bir haber dikkat çekici. BBC Türkçe'de çıkan haber Londra'da 1665-1666 yıllarında yaşanan Büyük Veba Salgını'na yol açan bakterinin özellikleri ilk kez DNA testleri ile ortaya çıkarıldığını belirtiyor (Stanbridge, 2016).

Gazetecilik tarihi birçok ilklere işaret etse de ilk gazete olarak üzerinde birleşilen Acta Diurna'dan (Danesi) günümüze, gazetecilik her dönem sosyal bir ihtiyaç olmuş, insanlık tarihinin gelişmelerine tanıklık etmekle birlikte bulunduğu dönemin sosyal ve siyasal yapısına göre içerik ve şekil açısından değişikliklere uğramıştır.

Türkiye'de gazetecilik ve edebiyat ilişkisi, Tanzimat dönemindeki yoğun gazetecilik çalışmaları sonucu önemli bir ivme kazanmıştır. Bu süreçte Türk basın hayatı hızlı ve değişken bir seyir izlemiştir. Hem bir ihtiyaç olarak hem de içerik açısından edebiyat ve edebiyatçıların gazete ve gazetecilik kavramının toplumda yaygınlaşmasında büyük paylarının olduğu bir gerçektir.

Tanzimat edebiyatında gazete, dönemin düşünsel yapısından tutun da kültürel ve Türk düz yazısının gelişmesine kadar oldukça önemli bir yer tutar. Divan edebiyatının şiir ağırlıklı döneminden düz yazı dönemine geçişte gazetelerin payı yadsınamaz bir gerçektir (Koloğlu, 1995). Tanzimat yıllarında edebiyatla ilgili konularda gazetelerin öncülük ettiğini ve makale, haber, eleştiriler ile edebî eserlerin gazetelerde yayınlanması sürecinin Ceride-i Havadis'le başlayıp Tercüman-ı Ahval ve Tasvir-i Efkar'la birlikte hız kazandığını görmekteyiz. 
Tanzimat Fermanı ile başlayan batılılaşma hareketlerini yakından inceldiğimizde özellikle Avrupa örneklerine rastlayarak Avrupai Türk Edebiyatının da 1.Dönemini görmekteyiz. Bu dönemde gazetecilik edebiyat ilişkisi açısından en ürünsel ve yöntemsel gelişmelerin yaşandığı bunun en önemli örneğinin ise bir edebiyatçı olan Şinasi'nin 1860'da Tercüman-1 Ahval gazetesini çıkarması olarak gösterilebilir (İnuğur, 2005).

$\mathrm{Bu}$ dönemde Türk Edebiyatına birçok tür girmekle birlikte özellikle gazeteciliğin de edebiyat çevresinde gelişen bir faaliyet gibi algılandığı gerçektir. Çünkü edebiyat ürünleri olan makale, fıkra, haber, röportaj, sohbet, mülakat, anı, gezi,şiir, gibi pek çok eser halka ulaşmasında gazeteler aracılık etmiştir. Ahmet Hamdi Tanpınar'ın o döneme dair dediği gibi "hiçbir yerde gazete bizdeki role benzer bir rol oynamamıştır. (...) bütün işaretler ondan gelir. Kalabalık onun etrafında kurulur. Okumayı o yazar. Mekteplerin uzak bir gelecek için hazırladığı ocağı o tutuşturur."

Tanzimat dönemiyle birlikte gazetelerde şiirlere, hikâye, roman ve piyes tefrikalarına, makale ve eleştirilere yer verilmesi gazete takip eden okuyucuların edebiyatla daha fazla ilgilenmelerine yol açmıştır. Söz gelişi Ömer Seyfettin'in ilk hikâyesi olan "Tenezzüh" ten Namık Kemal'in Vatan Yahu Silistre sine kadar birçok edebiyat eseri gazeteler sayesinde halkla buluşmuş ayrıca polemikler yani edebiyat kaynakları da bu gazetelerden yürütülmüş, o zamanın moda tartışması eski edebiyat yeni edebiyat da bu gazetelerin köşelerinde yerini almıştır.

Edebi gazetecilik kavramı 20.yy referanslı bir kavram olsa da, edebiyat gazetecilik ilişkisinin literatür çalışmalarında ilgi çekici nitelikteki örneklerine de rastlanmaktadır. Amerika Birleşik Devletleri'nde 1973'te Tom Wolfe imzalı yayınlanan The New journalism (yeni gazetecilik) adlı antolojinin giriş yazısında yeni bir yazı ve yazar eğiliminden bahsedilmekte bunun kavramsal açılaması da edebi gazeteciliğe dayandırılmıştır. (Wolfe,1973) Wolfe yeni gazetecilikte olayları sade ve geleneksel bir dille anlatmanın ötesinde gazetecinin derinlemesine araştırma ve gözlem yaparak derlediği materyali mutlak formatına uydurma zorunluluğu olmadan daha edebi daha akıcı bir dilin hakim olduğuna işaret etmiştir. Wolf antolojisinde Amerikan edebiyatının önemli isimlerinden biri Truman Capote, iki kere Pulitzer ödüllü yazar Norman Mailar gibi isimlerin kaleme aldıkları röportajlarda bu yeni yazın türünün seçkin örnekleri olarak sunulmuştur.

\subsection{Gazetelerde Edebi İçerikler}

Filizok'a göre, dilin sanat görevine dayanılarak söylenmiş bütün sözler edebîdir. Bir edebiyat eseri bir edebî metin olabileceği gibi, bir reklam metni, bir seçim afişi, bir gazete haberi de dil sanat görevinde kullanılmışsa edebî metindir. Bu bir "içerik (muhteva)" meselesi değildir, bu bir "biçim (şekil)" meselesidir: Edebî metinlerde anlam, mesajın bizzat biçimi aracılığıyla verilir (Filizok, 2013).

Devran, medyanın olayları yeni bir dille yeniden inşa ettiğini, anlaşllır kılıp ve dahası temsil ettiği ideolojiyi yeniden yapılandırarak kamuoyuna sunduğunu habere konu olan "olay"ın da medyanın kullandığı farklı söylemlerle farklı anlamlar 
kazandığını belirtirken aslında haber anlatım yöntemlerindeki değişkenliği de görmemizi sağlıyor (Devran, 2010).

Gazeteciliğin temel işlevi haber vermektir. Yani gazetecilik çoğunlukla habercilik olarak algılanmaktadır. Haber dilinde de, zihniyeti ifade eden yapı, anlatım, tema unsurları metinden seçilmeli ve bu noktadan hareketle metnin ait olduğu zihniyet ortaya çıkmaktadır. Michael Foucault'nun "discourse", Althusser'in "ideoloji" terimleri Türkçe'nin anlam dünyasında terim olarak kullanılan zihniyet kelimesiyle ifade edilebilir. Anlatımsal haberciliğin endüstriyel gazetecilik standardı olan sade habercilik içindeki yeri çok önemlidir (Tokgöz, 2002).

Aktaş'a göre edebî metnin dili, doğal dilden hareketle gerçekleştirilen yeni bir dildir. Doğal dil, her gün herkesin iletişimde kullandığı dildir. Sanatçı, farklı bir yapıyı, bir kurguyu, özel bir duyarlılığı, bir duygu halini daha güzel ve etkili anlatmak için her düzeydeki dil öğelerine yeni anlam ve değerler yükler. Amacı öğretmek değil, değiştirip dönüştürdüğü gerçekliği anlatmak; okuyucuya estetik yaşantı uyandırmaktır. Bunun için dile bireysel değerler yükler (Aktaş, 2015).

Edebî metin, pek çok farklı unsurdan meydana gelmiş bir "bütün”, estetik bir "terkip"tir. Muhteva, yapı, dil, bu terkibin ana unsurlarını; kelime, ibare, cümle, paragraf, metin halkası, bölüm; mısra, bend, nazım şekli; vezin, kafiye, redif, lâfız ve mana sanatları; konu, tema, anafikir, mesaj; olay örgüsü, şahıs kadrosu, zaman, mekân, anlatıcı vb. şeyler de ana unsurların alt unsurlarını oluştururlar (Çetişli, 2001).

Kuiken'e göre Edebîlik, öncelikle dil potansiyelini, söz varlığının hissedilmesini ve özalgıyı içine alan ruhsal kalıtımımızın bir sonucudur. Sahip olduğumuz potansiyellerden hareketle, edebî metin karşısındaki duruşumuz ve ona karşı tepkimiz, kendimize, içinde yaşadığımız topluma ve doğal çevreye ait farklı bakış açları geliştirmede önemli bir rol oynamaktadır (Miall ve Kuıken, 2014).

\section{Araştırma-Gazetelerin edebi içerik açısından incelenmesi}

\begin{tabular}{|l|l|}
\hline Hipotez & Günümüzde gazetelerde edebi içerikli haberlere az yer verilmektedir. \\
\hline Soru 1 & Gazetelerde çıkan haberlerin sayısı nedir? \\
\hline Soru 2 & Gazetelerde öğretici metin türlerinin Edebiyat yazı türleri nelerdir? \\
\hline Soru 3 & Gazetelerdeki haberlerin tamamında 5N 1 K kullanılmış mıdır? \\
\hline Soru 4 & Gazetelerde edebi haberlerin sayısı nedir? \\
\hline
\end{tabular}




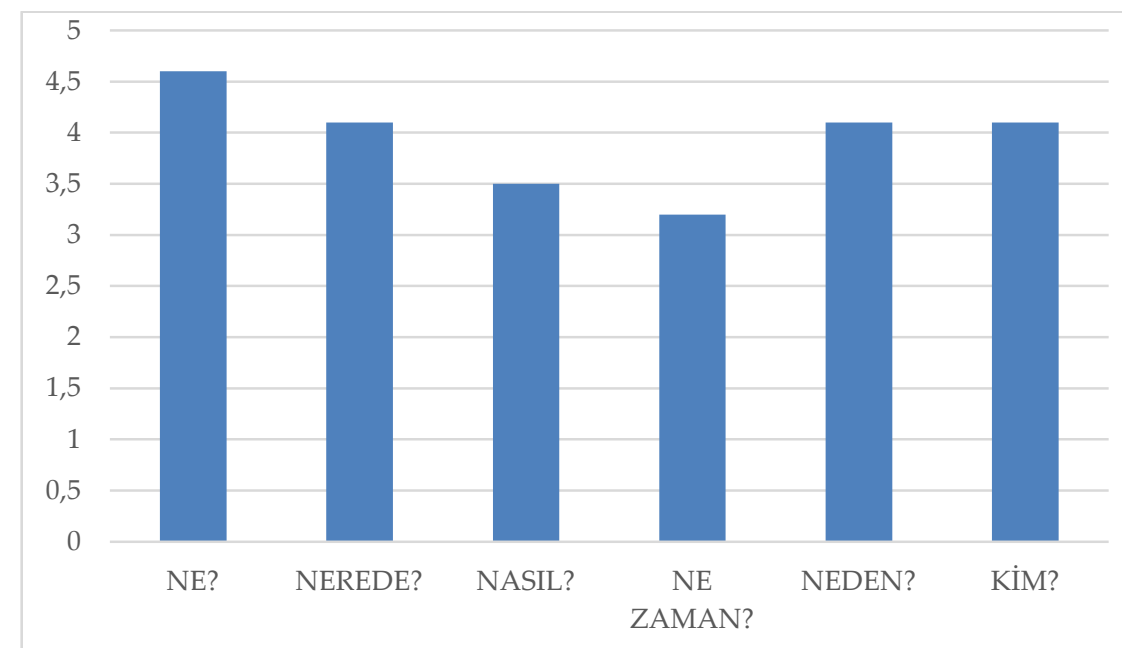

Grafik 1: 3-10 Ekim Tarihleri Arasında Yayınlanan Haberlerin 5N1K Açısından Yüzdeleri

Söz konusu gazetelerdeki tüm haberler incelendiğinde üzerinde yapılan incelemede Haber yazımında 5N $1 \mathrm{~K}$ kuralının öyküsel anlatım tarzının metinleri arasına yerleştiğini görüyoruz. Ancak bu haber yazım tarzında geleneksel haber yazım tarzı gibi 5 N 1 K kuralı ile ilgili olarak kesin çizgilerin olmadığını görüyoruz.

\section{ÖRNEK HABER}

Bir insan kaçakçısının ibret dolu hikâyesi

Banu ŞEN / İZMIR

26.09.2015 - 19:50 | Son Güncelleme: 26.09.2015 - 19:50

Hürriyet, insan kaçakçılı̆̆ının merkezi haline gelen İzmir Basmane'de insan tacirlerinin izini sürdü. 7 ay insan kaçakçıllğ̆ yapmış olan A., 'ya ulaştl, her şeyini kaptırmış olan Z. ve her an gitmeyi bekleyen M.'nin hikâyeleri de çaresizliğin ne boyutlara vardığını bir defa daha ortaya koydu.

Araştırmamızda incelenen haberlerden biri Hürriyet gazetesinde 26.09.2015 tarihinde çıtı.

Haberin başlığına bakıldığında "ibret dolu" söylemiyle haberin içindeki trajediye yönlendirme yapılmaktadır. Başlıkta yer alan "hikayesi" kelimesi ise haberde edebi unsurların varlığını vurgulamaktadır. Bu haberde edebiyat türü olan hikaye kelimesi kullanılarak öyküleme tekniğinin işlendiği gözler önüne serilmiştir. Yine haberin girişinde geleneksel haber yazım unsurlarının yani $5 \mathrm{~N} 1 \mathrm{~K}^{\prime}$ den bazı unsurların da yer aldığını görmekteyiz. Olay İzmir'de geçmekte ve olayın ne olduğuna dair fikir vermektedir. 


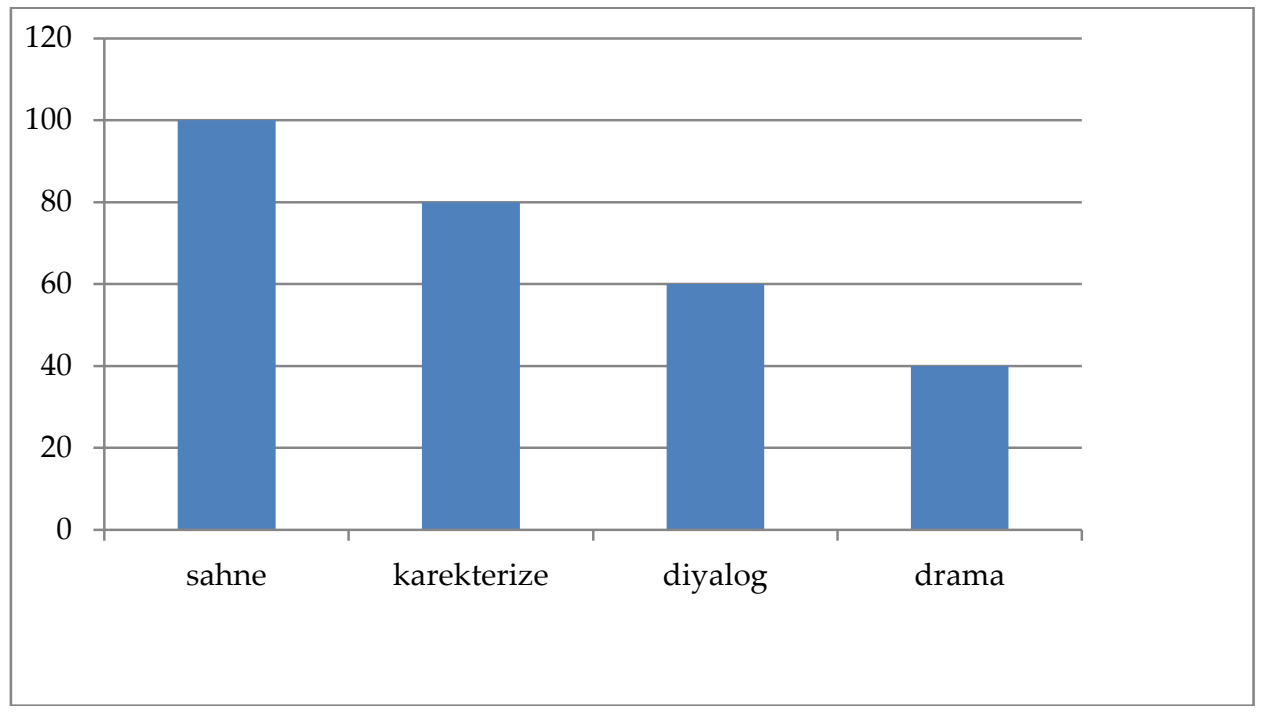

Grafik 2: 3-10 Ekim Tarihleri Arasında Yayınlanan Haberlerin Analizi

\section{BULGULAR}

\subsection{3-10 Ekim Gazetelerde Çıkan Edebi İçerikler}

Edebi içerikler açısından bakıldığında özellikle sahneleme olay örgüsü içerisinde mekân tasvirinin bu tarz haberlerde daha fazla kullanıldığını görmekteyiz. Edebi eserlerde kişilerin yaşadıkları fiziksel çevre içinde ele alınması, çevre ile insan öğesi arasında bütünlük kurulmasını sağlamakta ve bunun da gerçekliği arttıracağ vurgulanmaktadır. Haberin de gerçek olayların aktarımı olduğu göz önüne alındığında mekânsal tasvirin edebi haberlerde içerik artırıcı olduğu ortaya çıkar. Bunun yanı sıra haberin aktörlerinin tasvir edilmesi dramatik unsurların haber formatında yer alması içeriğin daha akıcı ve gerçeğe uygun olmasını sağlar.

Tablo 1: 3-10 Ekim Tarihleri Arasında Çıkan Haber Sayıları

\begin{tabular}{|c|c|}
\hline Gazeteler & Haber Sayıları \\
\hline HÜRRIYYT & 103 \\
\hline SABAH & 80 \\
\hline CUMHURİYT & 65 \\
\hline HABERTÜRK & 102 \\
\hline
\end{tabular}

3-10 Ekim 2017 tarihinde yayınlanan gazetelerde yapılan incelemede günde ortalama gazetelerde çıkan haber sayıları belirlenmiştir. Haber sayılarının özellikle merkez medya içeriklerinde daha fazla olduğu tespit edilmiştir. 


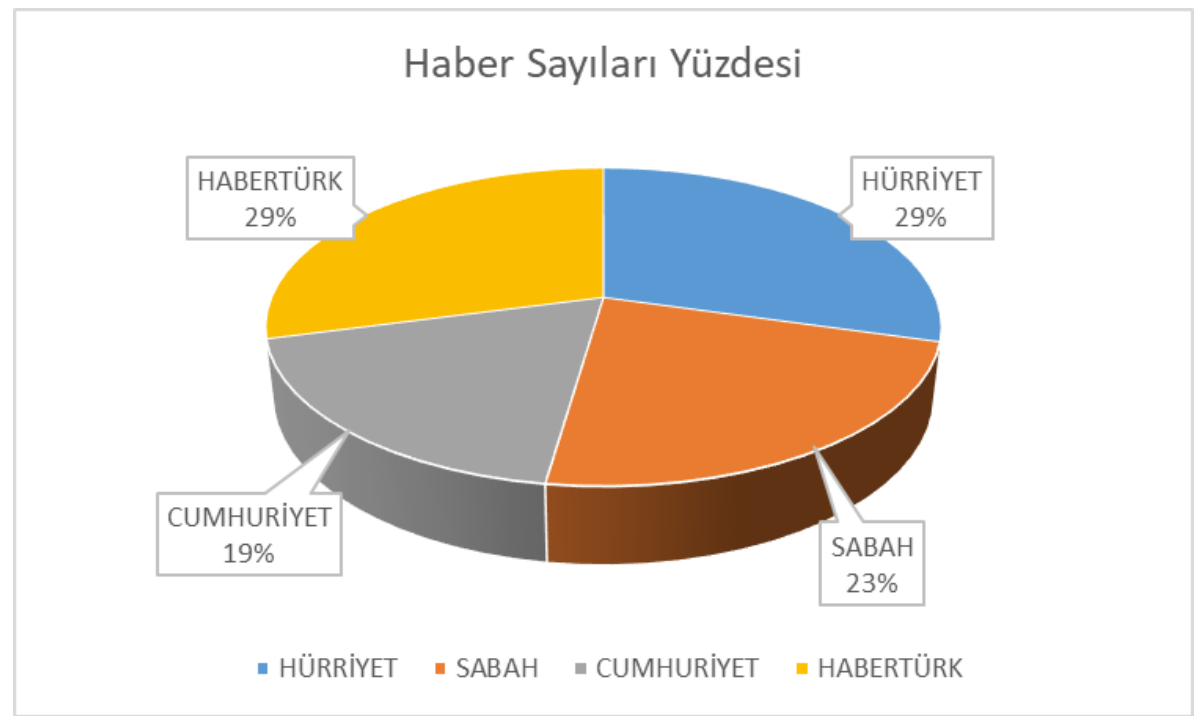

Grafik 3: 3-10 Ekim Tarihleri Arasında Haber Sayıları Yüzdesi

Tablo 2: 3-10 Ekim Tarihleri Arasında 5N 1K'nın Tamamı Kullanılan Çıkan Haber Sayıları

\begin{tabular}{|c|c|}
\hline Gazeteler & Haber Sayıları \\
\hline HÜRRIYET & 25 \\
\hline SABAH & 14 \\
\hline CUMHURIYET & 9 \\
\hline HABERTÜRK & 17 \\
\hline
\end{tabular}

\section{3-10 Ekim Tarihleri Arasında 5N 1K'nın Tamamı Kullanılan Çıkan Haber Sayıları}

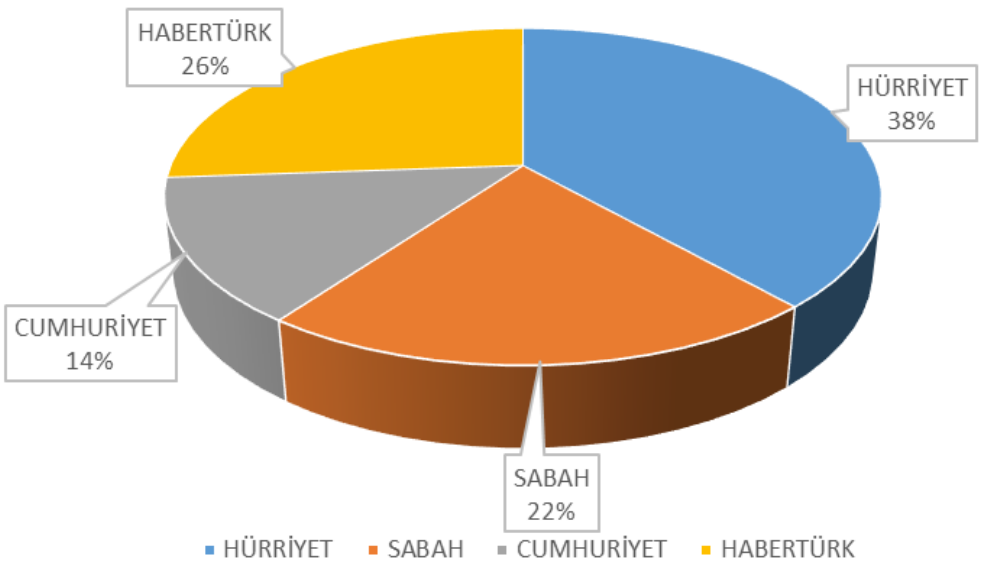

Grafik 4: 3-10 Ekim Tarihleri Arasında 5N 1K'nın Tamamı Kullanılan Çıkan Haber Yüzdeleri 
Gazeteciler için ters piramit öylesine olağan ve kabul gören bir tekniktir ki, adeta gazetecilik mesleği var olduğundan beri sanki bütün gazeteciler " $5 \mathrm{~N} 1 \mathrm{~K}$ ", "flaş gövde yapısı" gibi katı kurallara ve formüllere sahip bu anlatı kalıbını kullanıyormuş varsayımı tartışılmadan kabul görmektedir (Çı̆̆, 2010).

Tablo 2: 3-10 Ekim Tarihleri Arasında Kullanılan Edebi İçerikli Haber Sayıları

\begin{tabular}{|c|c|}
\hline Gazeteler & Edebi içerikli Haber Sayısı \\
\hline HÜRRIYYT & 12 \\
\hline SABAH & 11 \\
\hline CUMHURİYET & 5 \\
\hline HABERTÜRK & 5 \\
\hline
\end{tabular}

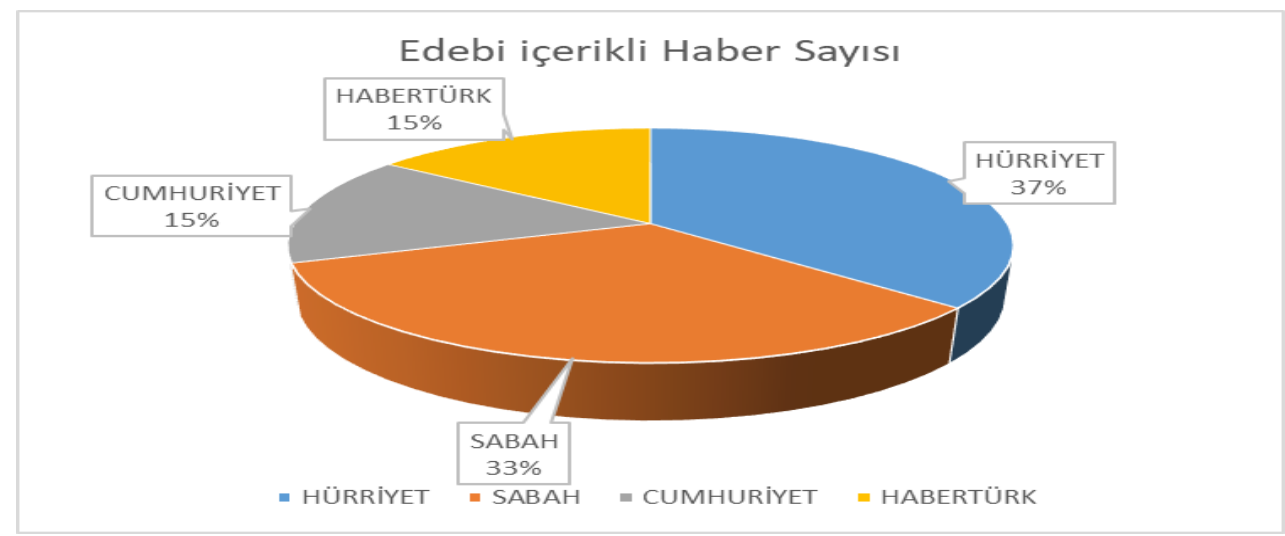

Grafik 5: 3-10 Ekim Tarihleri Arasında Edebi İçerik Kullanılan Haberlerin Yüzdeleri

\section{SONUÇ ve TARTIŞMA}

Haber yazımında 5N 1K kuralının öyküsel anlatım tarzının metinleri arasına yerleştiğini görüyoruz. Ancak bu haber yazım tarzında geleneksel haber yazım tarzı gibi 5N 1K kuralı ile ilgili olarak kesin çizgilerin olmadığını görüyoruz.

Edebi içerikler açısından bakıldığında özellikle sahneleme olay örgüsü içerisinde mekân tasvirinin bu tarz haberlerde daha fazla kullanıldı̆̆ını görmekteyiz. Roman kişilerinin fiziksel çevre içinde ele alınması, çevre ile insan öğesi arasında bütünlük kurulmasını sağlar ve bunun da gerçekliği arttıracağı öngörülmektedir. Haberin de gerçek olayların aktarımı olduğu göz önüne alındığında mekânsal tasvirin edebi haberlerde içerik artırıcı olduğu ortaya çıkar. Bunun yanı sıra haberin aktörlerinin tasvir edilmesi dramatik unsurların haber formatında yer alması içeriğin daha akıcı ve gerçeğe uygun olmasını sağlar. Haber sayılarının özellikle merkez medya içeriklerinde daha fazla olduğu tespit edilmiştir. Gazeteciler için ters piramit öylesine olağan ve kabul gören bir tekniktir ki, adeta gazetecilik mesleği var olduğundan beri sanki bütün gazeteciler " $5 \mathrm{~N} 1 \mathrm{~K}$ ", "flaş gövde yapısı" gibi katı kurallara ve formüllere sahip bu anlatı kalıbını kullanıyormuş varsayımı, tartışılmadan kabul görmektedir. 


\section{KAYNAKÇA}

\section{Kitaplar}

Chomsky, N. (1999). Medya Gerçeği. İstanbul: Tüm Zamanlar Yayıncılık.

Manoff, R. ve Schudson M. (1986). Reading The News, New York: Pantheon Books.

Galtung J ve Ruge M (1981). Structuring and Selecting News, The Manufacture of News, S. Cohen ve J. Young (ed), Sage, California.

İnuğur, N. (2005). Basın ve Yayın Tarihi, İstanbul: Der Yayınları.

Berger, A. (1982). Media Analysis Techniques. Beverly Hills: Sage.

Tokgöz, O. (2002). Temel Gazetecilik, İstanbul: İmge Yayınları

\section{Diğer Kaynaklar}

Aktaş, Ş. Edebî Metinleri Çözümleme Metodolojisi Ve Yapi-Tema İlişkisi Üzerine, 14 Nisan 2018 tarihinde http://www.ayk.gov.tr/wp-content/uploads/2015/01/AKTAŞ-Şerif-EDEBÎMETINLERI-ÇÖZÜMLEME-METODOLOJISİ-VE-YAPI-TEMA-İLIŞKISII-ÜZERINEE.pdf adresinde erişildi.

Çetişli, İ. (2001). Edebiyat Dili/Edebî Dil, Türk Yurdu Dergisi

Çı̆̆, Ü. (2010) Endüstriyel Bir Anlatı Yapısl: "Ters piramit" Haber Metinleri Dil ve Edebiyat Dergisi.

Duran, R. (2017) Medyatik istilaya cevap: Yavaş gazetecilik 14 Nisan 2018 tarihinde https://www.artigercek.com/medyatik-istilaya-cevap-yavas-gazetecilik/ adresinden erişildi.

Filizok, R. Edebi Metin Nedir? 3 Şubat 2018 tarihinde http://www.diledebiyat.net/edebi-metinnedir-riza-filizok-makale adresinden erişildi.

Koloğlu, Orhan, (1995), “Osmanlı'da Türkçe Dışı Basın”, Kebîkeç Dergisi.

Mıall, D. ve Kuıken, D. (2014). Edebîlik Ve Edebî Metinlerde Okuma Sürecinin Üç Bileşeni, Gazi Türkiyat Dergisi.

Stanbridge, N (2016). 4 Şubat 2018 tarihinde BBC Türkçe, Londra'daki Büyük Veba Salgını'nın Nedeni Kesinleştirildi, http://www.bbc.com/turkce/haberler-37305732 adresinden erişildi.

Wolfe, T.(1973) The New Journalism. Harper \& Row. 